Advances in Clinical Chemistry

Vol. 2. Edited by Harry Sobotka and C. P. Stewart. Pp. xiii +387. (New York: Academic Press, Inc.; London: Academic Press, Inc. (London), Ltd., 1959.) 12 dollars.

T TWO of the articles in this volume are primarily concerned with methods ("Paper Electrophoresis" by $H$. Peeters and "Automation" by W. H. Marsh). The four others survey certain selected biochemical fields. Dr. Peeters deals first with electrophoresis on strips and then with the lessfamiliar paper curtain electrophoresis. Factors underlying separations are examined in great detail and illustrated with many diagrams and tables. Much of the information is the author's original work which has been presented at the annual colloquia on proteins at Bruges. Dr. Marsh's article is timely in view of the increasing difficulties of obtaining personnel to cope with growing demands in clinical chemical laboratories. Simple as well as complex apparatus and processes are described and the article will be of special interest to those in charge of elinical chemical work. S. P. Bessman surveys the history, metabolism, measurement and pathological alteration of blood ammonia, and his article should stimulate interest in a subject the significance of which is not as widely appreciated as it ought to be. "Iodopathic Hypercalcæmia of Infancy" is a well-written review by J. O. Forfar and S. L. Thompsett, in which the clinical picture, biochemistry, ætiology and treatment of the disease, is covered. However, this article would possibly be more appropriate in a medical book rather than in this volume. E. J. Bigwood and associates provide a most valuable survey of aminoacid excretion in health and disease. Much of the data is quantitative and obtained by means of ion-exchange chromatography. Finally, "Bile Pigments in Jaundice" by Barbara $H$. Billing is an excellent account, including identification, chromatographic behaviour, methods of measurement and metabolism of these substances. Altogether, this well-produced second volume is full of interest for clinical chemists.

\section{R. CONSDEN}

Traité Général de la Fabrication des Colles des Glutinants et Matières d'Apprêts

Par Dr. Maurice de Keghel. Nouvelle édition, augmentée et remise à jour. Pp. ii +764 . (Paris : Gauthier-Villars, 1959.) 7,000 francs.

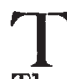

HIS new edition does not appear to be any appreciable improvement on the original version. The ground to be covered by a single authoranimal glue, vegetable adhesives, casein, synthetic resins, silicate adhesives, rubber, etc., in some sections including both manufacture and use-is so wide that full reforences to the sources of information are essential. No references are given throughout the book, the only indication of origin being a manufacturer's name for plant, and, very rarely, an author's name, without detailed reforence, for some experimental method. What basic scientific information is included is, in the main, unrelated to modern work. As an example, the conversion of collagen to gelatin is given as :

$$
\mathrm{C}_{302} \mathrm{H}_{149} \mathrm{O}_{38} \mathrm{~N}_{31}+\mathrm{H}_{2} \mathrm{O}=\mathrm{C}_{302} \mathrm{H}_{151} \mathrm{O}_{38} \mathrm{~N}_{31}
$$

This type of approach was already being superseded forty years ago when the equation was given in the text-books of that time. To-day it is not merely wrong, but also neglects the whole development of the concepts of the chemistry of macromolecules of the past thirty years.

The descriptions of plant and of industrial processes also neglect many recent developments which have changed the position of whole sections of the adhesives industry. The very large number of recipes for adhesives of various kinds are presented uncritically, with no attempts to explain the significance or function of the components used.

Certain methods of test are included. These appear to be selected at random, no reference being made to the versions accepted by the national standardizing bodies.

Neither for the manufacturer nor for the user of adhesives can this volume be said to servo a useful purpose, and less-informed readers would be misled by its many omissions and out-of-date information.

A. G. WARD

\section{The Hollow Universe}

By Prof. Charles de Koninck. (The Whidden Lectures, Series IV.) Pp. xii +127. (London: Oxford University Press, 1960.) 12s. 6d. net.

THE author of these lectures, now so attractively issued in book form, was not hampered by any rigid terms of reference, but could discuss what he liked and how he liked. Such opportunities are rare, and reflect credit upon the founder and the establishment of his trust. The theme is not altogether new; it displays the anxieties which are common enough at the ways things are going in the intellectual world. In brief, if we are nothing more than "a mere collection of occurrences", there will be (at the best) little left to wonder at in the whole domain of natural philosophy and human thought. Maybe this is so, but it makes something like nonsense of life as we known it. Prof. de Koninck is a very sensible person, and, moreover, fully alive to the claims of the positivists. His point is that in mathematical physics and everything related thereto one can, and must, be utterly impersonal, and regard Nature as purposeless.

But this does not necessarily apply to the biological sciences in which it is argued (very forcibly, in the reviewer's opinion) that an organism-that is, something provided with 'tools'-is meaningless if devoid of any teleological characteristics whatever. Incidentally, it is maintained that concentration on the lowest forms of life is not the best way to build up an understanding of Nature, any more than it is epistemologically rewarding to seek for goals and ends in plants, however fascinating, one may add, are the problems of morphology.

Thus, we are left with the tremendous question of the fundamentals of biophysics, and the advance of computers. Nobody is likely to ascribe wholly axiological judgments to mechanical systems for some time to come. That these judgments remain seem to make it probable that the universe is not entirely hollow. F. I. G. Rawlins

Theories of Figures of Celestial Bodies

By Wenceslas S. Jardetsky. Pp. xi+186. (New York : Interscience Publishers, Inc.; London : Interseience Publishers, Itd. 1958.) $45 \mathrm{~s}$.

NE of the deepest mysteries of the universe is that everything in it rotates. This remark, by the late Sir Arthur Eddington, probably explains why the theory of figures of celestial bodies has 